\title{
THE
}

\section{Habitat Characteristics Associated with the Distribution and Abundance of Histrionicus histrionicus (Harlequin Ducks) Wintering in Southern New England}

\author{
Richard A. McKinney \\ Scott R. McWilliams \\ University of Rhode Island, srmcwilliams@uri.edu \\ Michael A. Charpentier
}

Follow this and additional works at: https://digitalcommons.uri.edu/nrs_facpubs

Terms of Use

All rights reserved under copyright.

\section{Citation/Publisher Attribution}

McKinney, R. A., McWilliams, S. R., \& Charpentier, M. A. (2007). Habitat Characteristics Associated with the Distribution and Abundance of Histrionicus histrionicus (Harlequin Ducks) Wintering in Southern New England. Northeastern Naturalist, 14(2), 159-170. doi: 10.1656/

1092-6194(2007)14[159:HCAWTD]2.0.CO;2

Available at: https://doi.org/10.1656/1092-6194(2007)14[159:HCAWTD]2.0.CO;2

This Article is brought to you for free and open access by the Natural Resources Science at DigitalCommons@URI. It has been accepted for inclusion in Natural Resources Science Faculty Publications by an authorized administrator of DigitalCommons@URI. For more information, please contact digitalcommons-group@uri.edu. 


\section{BioOne

\section{Habitat Characteristics Associated with the Distribution and Abundance of Histrionicus histrionicus (Harlequin Ducks) Wintering in Southern New England}

Author(s): Richard A. McKinney, Scott R. McWilliams, Michael A. Charpentier

Source: Northeastern Naturalist, 14(2):159-170.

Published By: Eagle Hill Institute

https://

doi.org/10.1656/1092-6194(2007)14[159:HCAWTD]2.0.CO;2

URL: http://www.bioone.org/doi/

full/10.1656/1092-6194\%282007\%2914\%5B159\%3AHCAWTD

$\% 5 \mathrm{D} 2.0 . \mathrm{CO} \% 3 \mathrm{~B} 2$

BioOne (www.bioone.org) is a nonprofit, online aggregation of core research in the biological, ecological, and environmental sciences. BioOne provides a sustainable online platform for over 170 journals and books published by nonprofit societies, associations, museums, institutions, and presses.

Your use of this PDF, the BioOne Web site, and all posted and associated content indicates your acceptance of BioOne's Terms of Use, available at www.bioone.org/page/terms_of_use. 


\section{BioOne}

Usage of BioOne content is strictly limited to personal, educational, and non-commercial use. Commercial inquiries or rights and permissions requests should be directed to the individual publisher as copyright holder. 


\title{
Habitat Characteristics Associated with the Distribution and Abundance of Histrionicus histrionicus (Harlequin Ducks) Wintering in Southern New England
}

\author{
Richard A. McKinney,", Scott R. McWilliams², \\ and Michael A. Charpentier ${ }^{3}$
}

\begin{abstract}
Histrionicus histrionicus (Harlequin Ducks) that winter along the east coast of North America are listed as a population of special concern in Canada, and they use several coastal wintering sites in southern New England that are subject to varying degrees of urbanization. We studied patterns of habitat use by Harlequin Ducks at 12 known wintering sites in southern New England. An average of $327 \pm 114$ Harlequin Ducks were found at the sites during the winters of 2001-2003. More Harlequin Ducks wintered at sites south of Cape Cod, MA that had greater mollusk $(709,133 \pm 504,568$ versus 97,154 $\left.\pm 72,427 \mathrm{kcal} \mathrm{ha}^{-1}\right)$ and crustacean $(27,907 \pm 16,312$ versus $1412 \pm 1675$ $\left.\mathrm{kcal} \mathrm{ha}^{-1}\right)$ prey energy density, and a higher index of hunting activity $(2.4 \pm 1.2$ versus 1.4 \pm 0.5 ) than sites to the north. We used logistic regression analysis at 12 sites inhabited by Harlequin Ducks and 12 nearby sites of similar geomorphology that did not support Harlequin Ducks to identify habitat characteristics that best explained their distribution in southern New England. Our analysis identified two habitat characteristics that affected the likelihood a site was used by Harlequin Ducks: 1) the proportion of residential, commercial, and industrial land use within a $100-\mathrm{m}$ radius of the perimeter of the site; and 2) distance to the nearest Harlequin Duck wintering site. However, other factors, including those related to their extremely low population size, need to also be considered as recommendations are developed for the conservation of east coast Harlequin Ducks.
\end{abstract}

\section{Introduction}

Histrionicus histrionicus Linnaeus (Harlequin Ducks) are sea ducks that breed in remote stream reaches and frequent turbulent coastal marine habitats in winter. Two of the four populations of Harlequin Ducks are found in North America (CWS 1997), and declines were noted in the eastern Canadian population by the late 1980s. Recognition of these declines led to their being designated as endangered by the Committee on the Status of Endangered Wildlife in Canada in 1990, and subsequently down-graded to a "species of special concern" upon reevaluation in 2001. Harlequin Ducks were added to Canada's Species at Risk Act in 2003 (P. Thomas, Canadian Wildlife Service, Mount Pearl, NL, Canada, pers.

${ }^{1}$ US Environmental Protection Agency, Office of Research and Development, National Health and Environmental Effects Research Laboratory, Atlantic Ecology Division, 27 Tarzwell Drive, Narragansett, RI 02882. ${ }^{2}$ Department of Natural Resources Science, University of Rhode Island, Kingston, RI 02881. ${ }^{3}$ Computer Sciences Corporation, 27 Tarzwell Drive, Narragansett, RI 02882. "Corresponding author - mckinney.rick@epa.gov. 
comm.). These listings highlight the need for studies examining Harlequin Duck behavior and ecology on both their breeding and wintering grounds (Robertson and Goudie 1999).

Research priorities for the conservation of North American Harlequin Ducks include documenting the impact of human activity and disturbance near their wintering grounds (Robertson and Goudie 1999). Harlequin Ducks may be particularly vulnerable while concentrated on their wintering grounds, where even small, localized disturbances can affect substantial portions of the population (Goudie and Ankney 1986). Threats to wintering Harlequin Ducks include over-harvesting, oil spills, and, particularly in urban areas, loss of habitat caused by development. In addition to investigations into the impacts of direct human disturbance such as hunting and oil spills (Esler et al. 2000b, 2002; Lance et al. 2001), several studies have examined winter habitat use by North American Harlequin Ducks in relation to location, site morphology, and food availability (Esler et al. 2000a, Goudie and Ankney 1988, Mittlehauser et al. 2002). However, no studies have examined the impact of human activity adjacent to Harlequin Duck wintering grounds, even though significant numbers of Harlequin Ducks winter in areas that are increasingly under pressure from urbanization.

In this study, we examined patterns of habitat use by Harlequin Ducks wintering in southern New England, an area characterized by widespread coastal development that is host to about one fifth of the estimated 1800 Harlequin Ducks wintering on the east coast of North America (Mittlehauser 2000, Montevecchi et al. 1995). Our primary objective was to identify habitat characteristics that are associated with the distribution and abundance of Harlequin Ducks during winter in southern New England. We compared characteristics between sites inhabited during winter by Harlequin Ducks and nearby sites with similar geomorphology that do not support wintering Harlequin Ducks. We also compared Harlequin Duck abundance and habitat characteristics to the north and south of Cape Cod, MA, traditionally considered a dividing line for the southern New England marine environment (Roman et al. 2000). Differences in wintering-site use to the north and south of the Cape could have consequences for Harlequin Duck conservation since southern sites are often subject to increased development pressures.

\section{Methods}

\section{Study sites}

Our study sites included twelve locations from Cape Ann, MA to Point Judith, RI known to regularly support at least four Harlequin Ducks during winter (Fig. 1). In order to compare characteristics of used and unused sites, we included an additional 12 nearby sites of similar area and geomorphology at which wintering Harlequin Ducks were not regularly observed. The criteria for determining that a site was not used by Harlequin Ducks were 1) no ducks were present during surveys, and 2) there was no evidence 
of past use by more than 2 Harlequin Ducks during repeated observations by avian ecologists familiar with the survey areas (W. Petersen and S. Perkins, Massachusetts Audubon, Lincoln, MA, pers. comm.). The study sites consisted of rocky headlands, shallow coves, or sand beaches. In all cases, we delineated the sites using natural breaks in the topography of the site: a line drawn from shoreline to shoreline on either side of the peninsula for rocky headlands; a line drawn through the cove mouth for shallow coves; and for sandy beach areas, a line drawn perpendicular to the shoreline at a feature such as a natural or man-made jetty or rock outcropping beyond which Harlequin Ducks were not observed. All sites were similar in mean water depth (range 0.9-8.1 m [mean low water]; mean $=3.8 \mathrm{~m}$ ), and shoreline length $($ range $0.4-4.8 \mathrm{~km}$; mean $=1.3 \mathrm{~km}$ ).

\section{Waterfowl surveys}

Harlequin Duck abundances for Massachusetts sites (Fig. 1) were from single surveys during the winters of 2001-2002 and 2002-2003 using a 32$60 \mathrm{x}$ spotting scope or through $10 \times 50$ binoculars from a vantage point or points from which the entire surface of the site could be viewed. Abundances

Figure 1. Location of 12 southern New England Harlequin Duck wintering sites, 2001-2003, and 12 unused sites chosen for habitat comparison. Presence and absence refer to winter use by Harlequin Ducks. 1 $=$ Hodgkins Cove, 2 = Lanes Cove, 3 = Folly Point, 4 = Halibut Point, $5=$ Andrews Point, $6=$ Cathedral Ledge, $7=$ Gull Point, 8 = Gap Cove, $9=$ The Glades, $10=$ Minot Beach, $11=$ Lighthouse Point, 12 = Standish Road, $13=$ Sankety Head, $14=$ Squam Head, 15 = West Jetty, 16 = Eel Point, $17=$ Squibnocket, $18=$ Gay Head, 19= Warren Point, 20 = Sakonnet Point, $21=$ Sachuest Point, 22 = Beavertail Point, $23=$ Bonnet

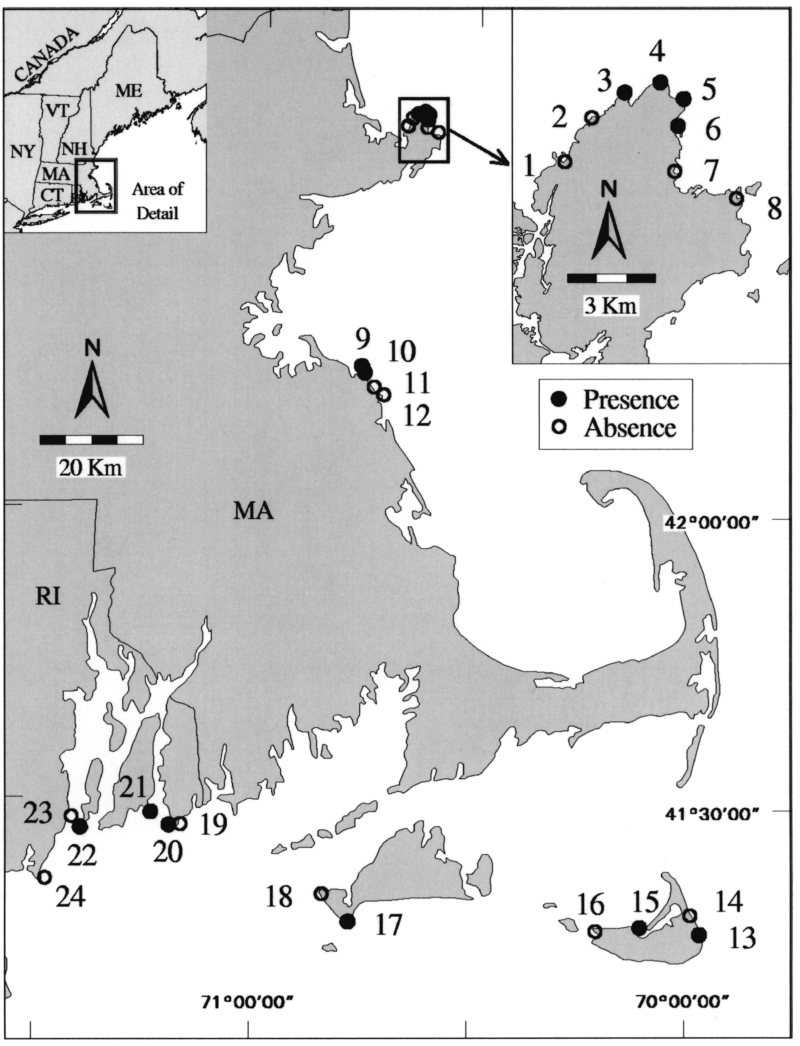
Point, 24 = Point Judith. 
for Rhode Island sites were calculated from census data collected during the winters (November through April) of 2001-2003. Bimonthly censuses at sites were performed on randomly chosen days and at randomly chosen times of day.

\section{Habitat characteristics}

Habitat characteristics were developed using geographic information system (GIS) topographic databases. The GIS data (e.g., shorelines, land use, and land cover) were obtained from the Rhode Island (RIGIS) and Massachusetts (MassGIS) geographic information systems and were processed using Environmental Systems Research Institute (ESRI) ARC GIS software (Redlands, CA). Shoreline data were derived from 15-minute (1:24,000 scale) United States Geological Survey (USGS) topographic maps. Land-use and land-cover data were developed from 1995 aerial photography (1:24,000 scale) coded to Anderson modified level 3 (Anderson et al. 1976) to one-half acre minimum polygon resolution. Shoreline data were used to determine linear shoreline length. In order to calculate surrounding land use, we first delineated a 100-m buffer adjacent to a site by drawing a $100-\mathrm{m}$ wide polygon parallel and upland of the shoreline, or high-water mark. We then used land-use and land-cover data from within the buffer to calculate the percent vegetated land (open land, forested, and wetland) and developed land. Developed land (DEVL) included the landuse categories residential, commercial, and industrial land. We chose a 100-m buffer because development and resultant human activity near the shoreline could potentially influence resident Harlequin Ducks. We measured the direct distance in $\mathrm{km}$ from the center of a site to the nearest stream mouth (NSTR) and to the center of the nearest adjacent site where Harlequin Ducks were present (NWFS). An intertidal slope estimate for each site (ITSL) was determined by first using bathymetry data for each site to generate a 2-m depth contour. The area between the shoreline of each site and the 2-m depth contour was calculated and then divided by the shoreline length. This provided a mean distance to the 2-m depth contour. By dividing the mean distance into the $2-\mathrm{m}$ depth, a mean value of slope was estimated. To determine a fetch value for each site (FETC), the grid module of Arc Info was utilized. The grid module includes a visibility tool that uses an elevation model to determine what is visible from a given location. By using an elevation model of each site that included the ocean as a flat area, the open ocean area that is visible from the shoreline of each site was determined. Fetch was calculated as the area of an arc that consists of open ocean area, described by the shoreline of the site projected out to $15 \mathrm{~km}$. Fetch can be considered a surrogate for potential wave exposure; greater fetch represents greater open ocean exposure and hence greater potential for wave exposure. All habitat characteristics were determined from archived data; therefore, only one measurement was made of each characteristic, and these values were used in constructing habitat models. 
We used intertidal quadrat sampling to measure the abundance of benthic invertebrates that could serve as prey for Harlequin Ducks. Three 75-m transects were laid out parallel to the shoreline within the intertidal zone at each site. The transect location both horizontally (i.e., its starting point within the intertidal zone of the site) and vertically (i.e., its relative position with respect to the mean low-water and mean high-water lines) was chosen using a probability-based random sampling protocol (Paul et al. 2003). Three $1-\mathrm{m}^{2}$ quadrats were placed equidistant along each transect, and all invertebrates were removed by hand or with a trowel if heavily encrusted with barnacles and macroalgae. Invertebrate samples and barnacle assemblages were passed through a $0.5-\mathrm{mm}$ sieve and immediately sorted, counted, and measured. Macroalgae-consisting primarily of rockweeds Fucus spp. and Ascophyllum mackaii (Linnaeus), but occasionally Chondrus crispus (Linnaeus) J. Stackhouse (Irish moss)-within the quadrats was sampled by first moving the macroalgae to a container partially filled with seawater. Approximately 5 drops of a $10 \%$ formalin solution was then added to the container, mixed, and allowed to settle for 2 minutes. Invertebrates, consisting mostly of amphipods and isopods that escaped from the macroalgae, were then captured by sieving and were sorted and counted as above. Biomass of available soft tissue for each was calculated using existing allometric length-weight relationships. We calculated productivity at each site using known productivity-to-biomass relationships (Robertson 1979), and used these values along with speciesspecific tissue-energy densities to estimate energy density (McKinney et al. 2004). Species were aggregated by phylum to calculate available crustacean energy density (PREC), available mollusk energy density (PREM), and all available prey energy density (PREY).

An index of waterfowl hunting (HUNT; range: 1-5) was developed for each of the sites using the best available data on hunting trends for the Rhode Island sites (C. Allin, Rhode Island Division of Fish and Wildlife, West Kingston, RI, pers. comm.), observations made during sampling events, and input from avian ecologists familiar with the survey areas (W. Petersen and S. Perkins, pers. comm.). Sites at which waterfowl hunting was prohibited by state waterfowl hunting regulations were assigned an index value of 1 . Those at which hunting was allowed, but which had only occasional hunting activity documented, were assigned a value of 3 . Sites where hunting was allowed and regular hunting activity had been documented and observed during waterfowl census events were assigned a value of 5. Other sites were assigned intermediate values depending on the level and documentation of hunting activity.

\section{Statistical analysis and model development}

We used logistic regression analysis (Hosmer and Lemeshow 2000) to determine which habitat characteristics were most important in explaining distribution of Harlequin Ducks. For logistic regression analysis, we used a case-control sampling design that included the 12 known Harlequin Duck winter habitats and an additional 12 nearby sites of similar area and geomorphology that did not support Harlequin Ducks (Keating and Cherry 2005). The 
following variables were used for this analysis: nearest Harlequin Duck site (NWFS), fetch (FETC), intertidal slope (ITSL), prey density (PREY), distance to the nearest stream mouth (NSTR), and proportion of residential, commercial, and industrial land use within a $100-\mathrm{m}$ radius of the perimeter of the site (DEVL). Since we were using logistic regression as an exploratory technique to try to identify habitat characteristics that might be important in determining harlequin distribution, we relaxed the significance criteria for entry of variables into the model to $\alpha=0.1$. Results were reported only for variables that entered the model.

Analysis of variance (ANOVA) and Student's t-tests were used to test for differences in harlequin abundance between northern and southern sites. For this analysis, we used mollusk and crustacean prey energy density (PREM, PREC), the index of waterfowl hunting (HUNT), nearest Harlequin Duck site (NWFS), and intertidal slope (ITSL) as independent variables, and Harlequin Duck abundance as the dependent variable. Harlequin abundance and prey energy densities are reported as means \pm standard deviation. Statistical analyses were performed with SAS for Windows ver. 6.12 (Carey, NC).

\section{Results}

We observed on average 327 Harlequin Ducks per year at our study sites during the winters of 2001-2004 (Table 1). More Harlequin Ducks were found at sites south of Cape Cod $(196 \pm 61$ ducks per site per year) than at those north of the Cape $\left(130 \pm 53\right.$ ducks per site per year; $t_{5}=2.02, \mathrm{P}=$ 0.027). Southern sites had both the highest (Squibnocket, $79.9 \pm 15.2$ ducks per site per year) and lowest (Sakonnet Point, $5.4 \pm 5.5$ ducks per site per year) mean abundance.

Table 1. Abundance (number of ducks per site per year \pm SD) of Harlequin Ducks at southern New England wintering sites, 2001-2003.

\begin{tabular}{|c|c|c|c|c|}
\hline \multirow[b]{2}{*}{ Site } & \multirow[b]{2}{*}{ Location } & \multicolumn{3}{|c|}{ Harlequin Duck abundance } \\
\hline & & 2001-2002 & $2002-2003$ & Mean 2001-2003 \\
\hline Folly Point ${ }^{\mathrm{A}}$ & North & 6 & 12 & $8.9 \pm 4.1$ \\
\hline Halibut Point ${ }^{\mathrm{A}}$ & North & 67 & 51 & $59.0 \pm 11.3$ \\
\hline Andrews Point ${ }^{\mathrm{A}}$ & North & 11 & 7 & $9.1 \pm 2.8$ \\
\hline Cathedral Ledge $\mathrm{A}$ & North & 34 & 14 & $24.0 \pm 14.1$ \\
\hline The Glades $^{\mathrm{A}}$ & North & 13 & 17 & $15.0 \pm 2.8$ \\
\hline Minot Beach ${ }^{\mathrm{A}}$ & North & 19 & 9 & $14.0 \pm 7.1$ \\
\hline Sankety Head ${ }^{\mathrm{A}}$ & South & 19 & 35 & $27.1 \pm 11.3$ \\
\hline West Jetty ${ }^{\mathrm{A}}$ & South & 12 & 29 & $20.5 \pm 12.0$ \\
\hline Squibnocket $^{\mathrm{A}}$ & South & 69 & 91 & $79.9 \pm 15.6$ \\
\hline Sakonnet Point ${ }^{\mathrm{B}}$ & South & $6.8 \pm 11.0$ & $4.0 \pm 4.2$ & $5.4 \pm 5.5$ \\
\hline Sachuest Point ${ }^{\mathrm{B}}$ & South & $47.0 \pm 12.9$ & $51.9 \pm 9.0$ & $49.4 \pm 11.0$ \\
\hline Beavertail Point ${ }^{\mathrm{A}}$ & South & 1 & 20 & $10.5 \pm 13.4$ \\
\hline \multicolumn{4}{|l|}{ Total all sites } & $327.0 \pm 114$ \\
\hline $\begin{array}{l}{ }^{A} \mathrm{n}=1 \text { census per } \\
{ }^{\mathrm{B}} \mathrm{n}=12 \text { censuses }\end{array}$ & & & & \\
\hline
\end{tabular}


Sites to the south of Cape Cod had greater prey energy density of mollusks $\left(392,260 \pm 251,998\right.$ versus $87,868 \pm 76,424 \mathrm{kcal} \mathrm{ha}^{-1}$; ANOVA: df $=1, \mathrm{~F}=8.50, \mathrm{p}=0.02)$ and crustaceans $(31,605 \pm 20,304$ versus $512 \pm 7819$ $\mathrm{kcal} \mathrm{ha}^{-1}$; ANOVA: $\left.\mathrm{df}=1, \mathrm{~F}=14.1, \mathrm{p}=0.003\right)$, and a higher index of hunting activity $(2.3 \pm 1.4$ versus $1.3 \pm 0.5$; ANOVA: $\mathrm{df}=1, \mathrm{~F}=4.56, \mathrm{p}=0.04)$ than sites to the north (Table 2). Also, southern sites had greater distances to nearest Harlequin Duck sites $(4.35 \pm 2.39$ versus $0.31 \pm 0.80 \mathrm{~km}$; ANOVA: $\mathrm{df}=1, \mathrm{~F}=17.0, \mathrm{p}=0.002)$. Northern sites had higher mean intertidal slopes than southern sites $(0.051 \pm 0.021$ versus $0.024 \pm 0.024$; ANOVA: $\mathrm{df}=1, \mathrm{~F}=4.05, \mathrm{p}=0.07$ ).

Most habitat characteristics used in the logistic regression analysis were quite variable (Table 3), and only two characteristics were significantly related to presence/absence of Harlequin Ducks and so entered into the model (Table 4): DEVL (proportion of residential, commercial, and industrial land use within a 100-m radius of the perimeter of the site), and NWFS (distance to the nearest Harlequin Duck wintering site in $\mathrm{km}$ ). Wintering sites with Harlequin Ducks were on average closer to other sites with Harlequin Ducks $(2.33 \pm 2.66 \mathrm{~km})$ and had less developed land nearby (38.6 $\pm 28.1 \%)$ than wintering sites without Harlequin Ducks $(3.40 \pm 3.49 \mathrm{~km}$, $67.2 \pm 31.6 \%$, respectively) (Table 3 ).

\section{Discussion}

Along the northeast coast of the US, Cape Cod has traditionally been considered a dividing line for the marine environment, with different distributions of benthic and pelagic species often reported north and south of the Cape (Roman et al. 2000). Within our southern New England study area (i.e., from Cape Ann, MA to Narragansett Bay, RI), we found that more

Table 2. Habitat and landscape characteristics for wintering sites used by Harlequin Ducks to the north and south of Cape Cod, MA in southern New England during 2001-2003. Location = whether the site is to the north $(\mathrm{N})$ or south $(\mathrm{S})$ of Cape Cod; PREM = energetic content of invertebrate mollusk prey in kcal per hectare; PREC = energetic content of invertebrate crustacean prey in kcal per hectare; HUNT = index of hunting activity; NWFS = nearest Harlequin Duck wintering site; ITSL = intertidal slope $(\%)$. Values for PREM and PREC are means $\pm \mathrm{SD}$.

\begin{tabular}{lcrrrrr} 
Site & Location & PREM & PREC & HUNT & NWFS & ITSL \\
\hline Folly Point & N & $38,995 \pm 17,745$ & $227 \pm 163$ & 2.0 & 0.010 & 0.073 \\
Halibut Point & N & $76,447 \pm 50,509$ & $445 \pm 180$ & 2.0 & 0.010 & 0.049 \\
Andrews Point & N & $71,739 \pm 34,434$ & $418 \pm 178$ & 1.0 & 0.208 & 0.065 \\
Cathedral Ledge & N & $154,686 \pm 98,063$ & $901 \pm 454$ & 1.0 & 0.419 & 0.063 \\
The Glades & N & $58,623 \pm 23,003$ & $341 \pm 204$ & 1.0 & 0.591 & 0.036 \\
Minot Beach & N & $126,719 \pm 69,695$ & $738 \pm 310$ & 1.0 & 0.590 & 0.017 \\
Sankety Head & S & $762,368 \pm 71,668$ & $61,425 \pm 3482$ & 2.0 & 3.689 & 0.066 \\
West Jetty & S & $630,239 \pm 23,409$ & $50,779 \pm 2234$ & 2.0 & 7.567 & 0.002 \\
Squibnocket & S & $298,102 \pm 141,382$ & $24,018 \pm 1014$ & 2.0 & 6.838 & 0.012 \\
Sakonnet Point & $\mathrm{S}$ & $323,805 \pm 150,216$ & $26,089 \pm 1278$ & 5.0 & 1.700 & 0.019 \\
Sachuest Point & $\mathrm{S}$ & $94,941 \pm 45,571$ & $7649 \pm 3400$ & 1.0 & 4.081 & 0.020 \\
Beavertail Point & $\mathrm{S}$ & $244,104 \pm 23,409$ & $19,668 \pm 2234$ & 2.0 & 2.242 & 0.020 \\
\hline
\end{tabular}




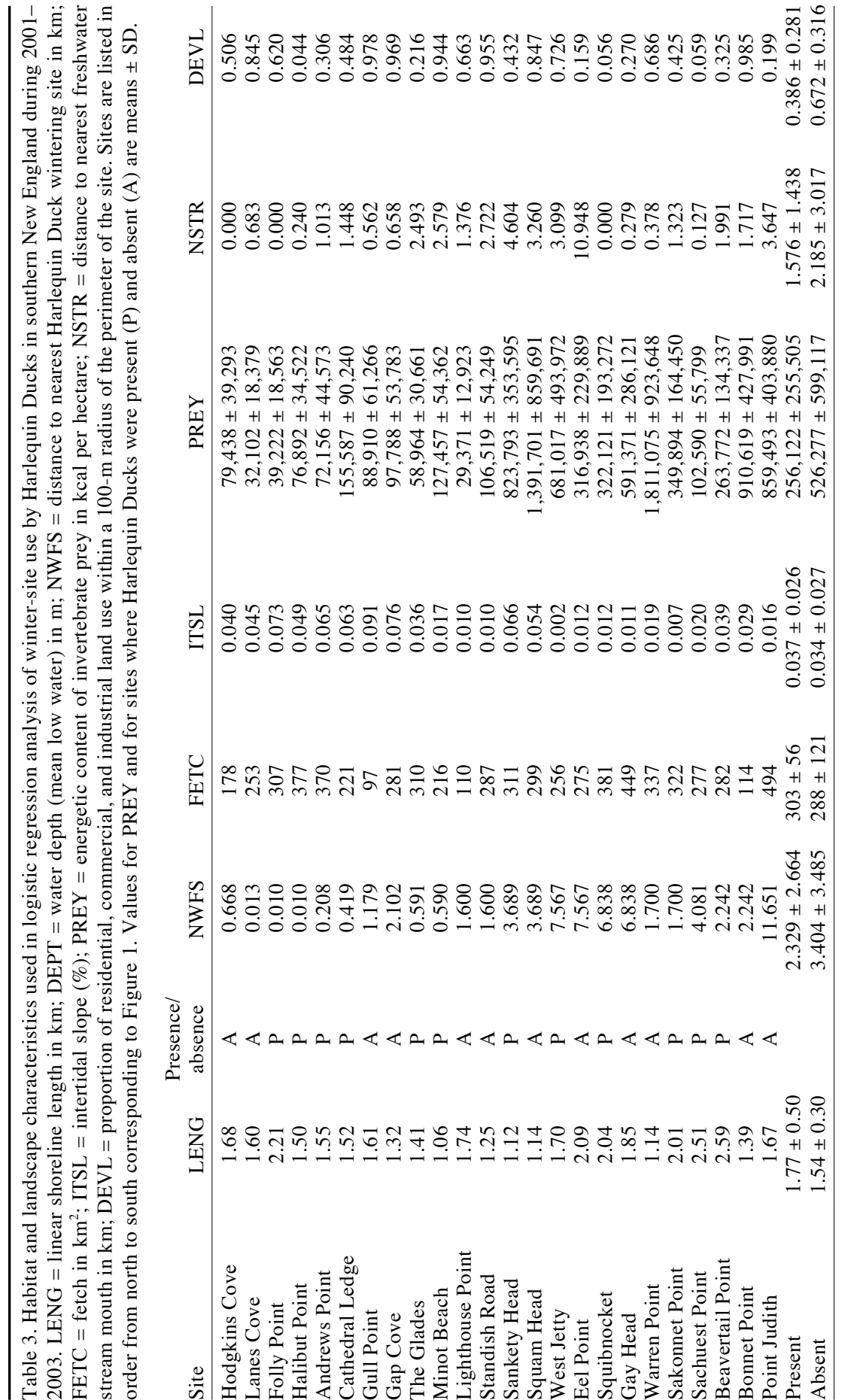


Harlequin Ducks wintered at sites south of Cape Cod and that these sites had greater prey energy density and lower intertidal slopes, which may make the benthic prey more accessible to foraging Harlequin Ducks. Thus, availability of good-quality foraging areas may in part explain the large-scale patterns of Harlequin Duck abundance in southern New England. However, we also found that sites south of Cape Cod had increased hunting activity, and greater distances between wintering sites. It is possible that Harlequin Ducks are enduring the costs (e.g., increased migration, higher disturbance) of wintering at more southerly sites in order to take advantage of more abundant and accessible prey.

The cumulative abundance of Harlequin Ducks reported at the 12 southern New England coastal wintering sites in our study (213-441 birds per year) comprised $12-25 \%$ of the estimated population of 1800 ducks wintering along the east coast of North America (Mittelhauser et al. 2002, Vickery 1988). Sites where Harlequin Ducks were present in southern New England averaged $38.6 \%$ developed land within a $100-\mathrm{m}$ radius of the shoreline, and the amount of developed land significantly influenced the distribution of Harlequin Ducks. Several recent studies examined the effects of increasing urbanization on breeding-bird species diversity and species composition (Jokimaki and Kaisanlahti- Jokimaki 2003, Melles et al. 2003, Salvati 2003); however, few studies have examined the effects of urbanization on waterfowl abundance. In our study, we used adjacent land use as a surrogate for urbanization and human disturbance, with the expectation that as urban land use increases, the potential for human disturbance (e.g., boat traffic, humans and pets walking the shoreline) in close proximity to wintering Harlequin Ducks also increases at a given site. We found that the presence of Harlequin Ducks at a given site was negatively influenced by the extent of developed land within a 100-m radius of the site. Thus, Harlequin Ducks that winter in southern New England are exposed and apparently respond to impacts from human disturbance.

In southern New England, Harlequin Ducks appear to exclusively use narrowly defined winter habitats year after year, a phenomena that may be related to the extremely high rates of site fidelity or philopatry shown to wintering and breeding sites by this species (Iverson et al. 2004; Robertson et al. 1999, 2000). We found relatively similar numbers of Harlequin Ducks

Table 4. Results of logistic regression analysis of Harlequin Duck abundance at southern New England wintering sites and adjacent sites with similar geomorphology using presence/absence as the dependent variables and additional habitat and landscape characteristics from Table 3. NWFS = distance to nearest Harlequin Duck wintering site in $\mathrm{km}$; DEVL = proportion of residential, commercial, and industrial land use within a 100-m radius of the perimeter of the site.

\begin{tabular}{lcccccccc} 
Site & $\mathrm{dF}$ & Estimate & $\begin{array}{c}\text { Standard } \\
\text { error }\end{array}$ & $\begin{array}{c}\text { Wald } \\
\text { chi-square }\end{array}$ & $\begin{array}{c}\text { Prob }> \\
\text { chi-square }\end{array}$ & $\begin{array}{c}\text { Odds-ratio } \\
\text { estimate }\end{array}$ & $\begin{array}{c}\text { 95\% Wald } \\
\text { confidence limits }\end{array}$ \\
\hline Intercept & 1 & 3.70 & 1.63 & 5.20 & 0.022 & - & - & - \\
NWFS & 1 & -0.364 & 0.206 & 3.12 & 0.077 & 0.69 & 0.46 & 1.04 \\
DEVL & 1 & -0.498 & 0.209 & 5.65 & 0.017 & 0.61 & 0.40 & 0.92 \\
\hline
\end{tabular}


between years at each site, although our analysis also showed that the likelihood of Harlequin Ducks being present at a site decreased with distance to the nearest occupied Harlequin Duck wintering site. This indicates that wintering Harlequin Ducks may prefer sites that are near other sites with Harlequin Ducks. Other birds are attracted to conspecifics, although this may lead to increased intra-specific competition (Davoren et al. 2003, Reed and Dobson 1993, Silverman et al. 2004). If true for Harlequin Ducks, then they may use conspecifics as indicators of habitat quality and so are attracted to wintering sites with other ducks, only to be displaced through intraspecific competition to nearby sites of suitable but lower quality habitat (Alonso et al. 2004).

Our findings have several implications for the management and conservation of wintering Harlequin Ducks in southern New England. First, given the negative effect of development on the presence of Harlequin Ducks at wintering sites, further development near currently used wintering sites should be limited. Second, our finding that proximity to nearby occupied sites may be influencing habitat selection of Harlequin Ducks during winter suggests that maintaining nearby clusters of suitable coastal wintering sites is important. Given the difficulty of accurately assessing habitat selection of small populations such as the east coast Harlequin Ducks (Greene and Stamps 2001), we encourage further studies to determine if these patterns are also evident when and where Harlequin Duck populations are more dense.

\section{Acknowledgments}

We would like to thank Wayne Petersen and Simon Perkins for assistance with identifying Massachusetts Harlequin Duck wintering sites and providing access to abundance data. We also thank Glen Mittelhauser for insightful discussions on east coast wintering Harlequin Ducks, and Jim Heltshe for advice and interpretation of logistic regression analysis results. Charlie Allin provided information about waterfowl hunting patterns in Narragansett Bay. We thank Peter Paton, Frank Golet, and Kathleen Melanson for reviewing and providing insightful comments on an earlier draft of the manuscript. Mention of trade names or commercial products does not constitute endorsement or recommendation. Although the research described in this article has been funded wholly by the US Environmental Protection Agency, it has not been subjected to Agency-level review. Therefore, it does not necessarily reflect the views of the Agency. This paper is the Office of Research and Development, National Health and Environmental Effects Research Laboratory, Atlantic Ecology Division contribution number AED-06-024.

\section{Literature Cited}

Alonso, J.C., C.A. Martin, J.A. Alonso, C. Palacin, M. Magana, and S.J. Lane. 2004. Distribution dynamics of a great bustard metapopulation throughout a decade: Influence of conspecific attraction and recruitment. Biodiversity and Conservation 13:1659-1674.

Anderson, J.R., E.E. Hardy, J.T. Roach, and R.W. Whitmer. 1976. A land-use and land-cover classification system for use with remote-sensor data. Geological Survey Professional Paper 964. US Geological Survey, Washington, DC. 
Canadian Wildlife Service (CWS). 1997. Conservation issues for North American sea ducks. A concept paper for a sea duck joint venture under the North American Waterfowl Management Plan. Canadian Wildlife Service (in cooperation with US Fish and Wildlife Service, and US Geological Survey - Biological Sciences Division), Gatineau, Quebec, Canada.

Davoren, G.K., W.A. Montevecchi, and J.T. Anderson. 2003. Distributional patterns of a marine bird and its prey: Habitat selection based on prey and conspecific behaviour. Marine Ecology Progress Series 256:229-242.

Esler, D., T.D. Bowman, T.A. Dean, C.E. O'Clair, S.C. Jewett, and L.L. McDonald. 2000a. Correlates of Harlequin Duck densities during winter in Prince William Sound, Alaska. Condor 102:920-926.

Esler, D., J.A. Schmutz, R.L. Jarvis, and D.M. Mulcahy. 2000b. Winter survival of adult female Harlequin Ducks in relation to history of contamination by the Exxon Valdez oil spill. Journal of Wildlife Management 64:839-847.

Esler, D., T.D. Bowman, K.A. Trust, B.E. Ballachey, T.A. Dean, S.C. Jewett, and C.E. O'Clair. 2002. Harlequin Duck population recovery following the Exxon Valdez oil spill: Progress, process, and constraints. Marine Ecology Progress Series 241:271-286.

Goudie, R.I., and C.D. Ankney. 1986. Body size, activity budgets, and diets of sea ducks wintering in Newfoundland. Ecology 67:1475-1482.

Goudie, R.I., and C.D. Ankney. 1988. Patterns of habitat use by sea ducks wintering in southeastern Newfoundland, Canada. Ornis Scandanavica 19:249-256.

Greene, C.M., and J.A. Stamps. 2001. Habitat selection at low population densities. Ecology 82:2091-2100.

Hosmer, D.W., and S. Lemeshow. 2000. Applied Logistic Regression, $2^{\text {nd }}$ Edition. J. Wiley and Sons. New York, NY. 378 pp.

Iverson, S.A., D. Esler, and D.J. Rizzolo. 2004. Winter philopatry of Harlequin Ducks in Prince William Sound, Alaska. Condor 106:711-715.

Jokimaki, J., and M.L. Kaisanlahti-Jokimaki. 2003. Spatial similarity of urban bird communities: A multiscale approach. Journal of Biogeography 30:1183-1193.

Keating, K.A., and S. Cherry. 2005. Use and interpretation of logistic regression in habitat-selection studies. Journal of Wildlife Management 68:774-789.

Lance, B.K, D.B. Irons, S.J. Kendall, and L.L. McDonald. 2001. An evaluation of marine bird population trends following the Exxon Valdez oil spill, Prince William Sound, Alaska. Marine Pollution Bulletin 42:298-309.

McKinney, R.A., S.M. Glatt, and S.R. McWilliams. 2004. Allometric length-weight relationships for benthic prey of aquatic wildlife in coastal marine habitats. Wildlife Biology 10:241-249.

Melles, S., S. Glenn, and K. Martin. 2003. Urban bird diversity and landscape complexity: Species-environment associations along a multiscale habitat gradient. Conservation Ecology 7:271-279.

Mittelhauser, G.H. 2000. The winter ecology of Harlequin Ducks in coastal Maine. M.Sc. Thesis. University of Maine, Orono, ME. $131 \mathrm{pp.}$

Mittelhauser, G.H., J.B. Drury, and P.O. Corr. 2002. Harlequin Ducks (Histrionicus histrionicus) in Maine, 1950-1999. Northeastern Naturalist 9:163-182.

Montevecchi, W.A., A. Bourget, J. Brazil, R.I. Goudie, A.E. Hutchinson, B.C. Johnson, P. Kehoe, P. Laporte, M.A. McCollough, R. Milton, and N. Seymour. 1995. National recovery plan for the Harlequin Duck in eastern North America. Report No. 12. Recovery of Nationally Endangered Wildlife Committee. Ottawa, ON, Canada. 30 pp. 
Paul, J.F., J.L. Copeland, M.A. Charpentier, P.V. August, and J.W. Hollister. 2003. Overview of GIS applications in estuarine monitoring and assessment research. Marine Geodesy 26:63-72.

Reed, J.M., and A.P. Dobson. 1993. Behavioural constraints and conservation biology: Conspecific attraction and recruitment. Trends in Ecology and Evolution $8: 253-256$.

Robertson, A.I. 1979. The relationship between annual production: Biomass ratios and lifespans for marine macrobenthos. Oecologia 38:193-202.

Robertson, G.J., and R.I. Goudie 1999. Harlequin Duck (Histrionicus histrionicus). No. 466, In A. Poole, and F. Gill (Eds.). The Birds of North America. The Birds of North America, Inc. Philadelphia, PA. 32 pp.

Robertson, G.J., F. Cooke, R.I. Goudie, and W.S.Boyd. 1999. Within-year fidelity of Harlequin Ducks to a moulting and wintering area. Pp. 44-50, In R.I. Goudie, M.R. Petersen, and G.J. Robertson (Eds.). Behavior and Ecology of Sea Ducks. Occasional Paper Number 100. Canadian Wildlife Service, Ottawa, ON, Canada. 88 pp.

Robertson, G.J., F. Cooke, R.I. Goudie, and W.S. Boyd. 2000. Spacing patterns, mating systems, and winter philopatry in Harlequin Ducks. Auk 117:299-307.

Roman, C.T., N. Jaworski, F.T. Short, S. Findlay, and R.S. Warren. 2000. Estuaries of the northeastern United States: Habitat and land use signatures. Estuaries 23:743-764.

Salvati, L. 2003. Distribution and relative abundance of wintering birds in a Mediterranean urban area: The influence of habitat variables. Biota 4:91-100.

Silverman, E.D., R.R. Veit, and G.A. Nevitt. 2004. Nearest neighbors as foraging cues: Information transfer in a patchy environment. Marine Ecology Progress Series 277:25-35.

Vickery, P.D. 1988. Distribution and population status of Harlequin Ducks (Histrionicus histrionicus) wintering in eastern North America. Wilson Bulletin 100:119-126. 